\title{
The Canatian Entamaloyist
}

\begin{tabular}{lll}
\hline \hline LXV ORILLIA, SEPTEMBER, I933 & No. 9 \\
\hline
\end{tabular}

\section{NORMAN CRIDDLE}

In the passing of Norman Criddle in his fifty-eighth year, the Entomological Branch of the Dominion Department of Agriculture lost a most valuable officer, the Province of Manitoba a noteworthy citizen, and Canada at large a naturalist of distinction. His devotion to the study of natural history, particularly to entomology, contributed in a marked degree to the material welfare of the Prairie Provinces.

During recent years Norman Criddle has not enjoyed very good health. His condition became alarming about the middle of April and he was forced to go into a hospital at Brandon on April 19. An operation was considered advisable and, after a short rest, this took place on April 28. Following the operation he improved for some days in a manner considered satisfactory to his doctors. Unfortunately, however, on May 3, he developed an acute attack of influenza which, owing to his depleted constitution, he was unable to throw off.

His death on May 4, I933, came as a great shock to his many friends, colleagues, and fellow entomologists not only throughout Canada but elserwere as well.

His decease was felt as a real calamity to the Dominion Department of A griculture, particularly the Entomological Branch of which he was a Senior and outstanding official, to the agricultural industry of the Prairie Provinces in the service of which he laboured so successfully, and to the science of natural history to which he had made important contributions.

Norman Criddle was a man of great kindliness, modesty and quiet. persistent industry, endowed with an artistic temperament and a love of music. He was equipped with a remarkable biological judgment which was controlled by study and guided by a great breadth of mind nurtured upon wide and thoughtful reading in science, literature and art. He was regarded with affection and admiration by his friends, colleagues and fellow scientists, and his personality was accorded the respect of even the most casual acquaintance.

Mr. Criddle was born at Addlestone, Surrey, England, on May I4th, I875, and with his parents came to Manitoba in I882. The family settled on a homestead near Aweme about 25 miles south of Brandon. His early education was received from his father and mother, both of whom were highly educated. Until about 1905 he lived continuously at Aweme and assisted generally in the work of the farn. In early July, Igoo, the late Dr. James Fletcher, then Dominion Entomologist, investigated an important outbreak of grasshoppers in southern Manitoba and in the course of his travels visited Aweme and spent the night of the 2nd at the home of the Criddles. Fletcher not only had a remarkable knowledge of natural history subjects generally, but he had in addition a most fascinating way of disseminating interesting information. Those who were fortunate enough to know Fletcher will appreciate the great pleasure Norman Criddle must have experienced on meeting him. From that time on the latter was a 
constant correspondent of the federal entomological service and there developed a real friendship between these two naturalists. Fletcher well appreciated the wide knowledge that Norman Criddle had acquired of insects and plants and recognized at once his skill in drawing even at this stage of his career.

Early in I905, Norman Criddle was called to Ottawa to complete coloured drawings of weeds and weed seeds for a publication by the Dominion Department of Agriculture, entitled, "Farm Weeds," by George H. Clarke and James Fletcher.* Soon after his arrival in Ottawa he attended a meeting of the entomological section of the Ottawa Field-Naturalists' Club at the home of the Senior author on January Igth, Igo5. 'This was his first attendance at a meeting of the Club and on this occasion he entertained the members with a description of the physical nature of that part of Manitoba in which he lived and directed attention to the exceptionally suitable character of the locality for the collection of insects and plants.

During the years I906-Ig Io he was engaged by the Dominion Seed Cominissioner to collect weed seeds which were used for the preparation of reference collections supplied to seedmen. In this work he was assisted by his brothers, mainly Evelyn and Stuart. In the winters of I9Io-I9I3 he was employed as a Seed Analyst by the Dominion Seed Branch with headquarters at Calgary, Alberta.

In the summer of I9I3, Mr. Criddle was employed by the Division of Entomology of the Experimental Farms Branch as a temporary Entomological Field Officer for Manitoba. This position was made permanent on April Ist, I9I4. In the reorganization of the federal entomological service of I9I9, Mr. Cridcile's title was changed to that of "Entomologist." This position he held until his death.

Mr. Criddle's skill in drawing not only served as a wonderful medium tor illustrating his own publications throughout his productive career but in addition to the coloured plates which were prepared for illustrating "Farm Weeds," he also prepared twenty-seven coloured drawings for a departmental publication issued in T913, "Fodder and Pasture Plants," by George H. Clarke and the late M. O. Malte.

Although Mr. Criddle's later work and that of greatest economic significance was concerned chiefly with grasshoppers and their control, his interest was in no sense confined to entonology and embraced in addition a range of natural history subjects such as, flowering plants, wild life as commonly understood, mammals and birds. All his investigations were carried on as a continuous study, in fact as parts of the whole web of prairie aninal life of which even the human population ranked as but one of the important constituents. The essential unity of his biological cosmos is very clearly shown by the dating of his publications (see appended list), in that from IgO4 on, no subject of major interest is ever far from print. It is part of the scientific tragedy that an urgent pre-occupation with the necessary duties as a field entomologist prevented his putting on record more of the great wealth of biological knowledge which his life of observation and study had stored in note and mind. Without question there was still in reserve a fund of information equal to that which 
he has left us.

His interest in entomology was of very long standing and was fundamentally philosophical. Throughout, the strictly biological was inextricably interwoven with the economic and any knowledge secured was always used in the service either of man or animal or both.

His first entomological publication was in rgo7 upon tiger beeties. However, even by Igol the econonic aspect of the subject had caught his attention and in that year he invented and with his neighbors demonstrated the value of the "Criddle Mixture" in grasshopper control as a substitute for the "bran bait" for use by the individual farmer. 'Though not definitely attached to the federai entomological service, he continued his studies of insects along with other natural history studies and, by I9I4, when he took up this branch of science professionally by joining the Entomological Branch he had already accumulated a vast store of information and had published eight papers which included both studies of particular insects and general appraisals of the insect situation over wide areas. After I9I4, with his attention definitely directed to insects as his major concern his lknowledge and influence in prairie entomology were soon felt and papers by Norman Criddle were watched for with increasing interest and respect till the day of his death.

It was in relation to the grasshopper problem that his most comprehensive work was accomplished. The study was pursued throughout his entire career and the total result added a priceless record to the fund of knowledge upon this vital problem in prairie agriculture. The life-history and habits of some 70 species of grasshoppers were made known and the identification of most of them was made possible to him in any stage of their life-history. The technical aspects of the study c1lminated in the papers filed for publication when he died, in one of which the egg-sacs of seventy-two species are described and figured as an aid in classification and identification, and a second, in which the ecological setting and food habits of 80 species are described, while another paper was in course of preparation making for the iclentification of the eggs from the study of the detail of their surface structure. During the course of these technical studies every shred of knowledge secured was directed towards the control of grasshoppers as a crop pest and Norman Cricldle's unquestioned leadership in the technical background for advising in this work throughout the prairie regions stood without challenge. His work, arlvice and prestige have leen the foundation upon which grasshopper control work on the Canadian prairies was built and carried on.

“Norman Criddle's interest in ornithology began when he came to the prairies of Manitoba as a boy. He has told me that he and his brother had no bird books, and so they had to invent names of their own for all the birds they iound near their Manitoba home. Another less enthusiastic boy would have done is most boys do, recognized that there were many kinds of birds, nicknamed a few, and let it go at that.

"Not long ago Mr. Criddle was in conversation with a snall group of naturalists when the subject of the Cowbird came up, and someone who had 110 use for this bird because of its parasitic habits spoke his mind to that effect. Mr. Criddle quietly remarked that anyone who had lived with Cowbirds as he 
had, and known them intimately, could not help but love them. He then told that when he was ploughing the Prairies with oxen the Cowbirds would be all over the oxen, and all over him all day.

"It seemed that Mr. Criddle, as in this case, always delighted in defending any bird or mammal that was under attack, and he always spoke or wrote his facts from a vast store of knowledge which contained much that the attacker had overlooked.

"For the sake of his great knowledge of wild life in general, and because he never took any but the most carefully balanced and sanest of views on intricate wild life problems, he was for many years a valued representative of the Department of Agriculture at the Provincial-Dominion Conferences of Game Officials, which have been called from time to time over a long period by the Department of the Interior. At these conferences he not only represented his Department faithfully and well, but he made many distinct additions to the programmes from year to year. His level-headed judgment on any problem was always welcomed by the delegates." (Mr. Hoyes Lloyd, June I4, I933).

"While Norman Criddle did not publish nany long papers on manmais, he was a recognized authority on the prairie forms, particularly on life-histories. He was also a frequent contributor to scientific periodicals on ecolugical subjects, usually containing important data on certain species. He was a:vays very generous in giving notes and observations to other workers who were interested, and on his annual returns to Ottawa after a field season in Manitoba always visited the National Museum to give information on recent developments in mammal and bird life in that Province. He remained a nember of the Ottawa Field-Naturalists' Club for half a lifetime, and became a charter memizer of the American Society of Mammalogists in IgI9, retaining his interest until the last.

"The Criddle family were all interested in natural history, and coming to Manitoba in 1882, when Norman was a small boy, he had abundant opportunities to hear the lore of the early days when the mamnal life, both game and fur, were the main resources of the country, and to learn from pe:sonal observation the important place filled by the smaller mammals in affecting farm life and crops, and the role of the predatory mammals in control of rodent and insect pests. Much of Norman Criddle's work on mammals was done in collaboration with his brother Stuart. 'They published several papers jointly, and some of Stuart Criddle's papers quote from the observations of his brothers Norman, Evelyn and Talbot.

"Norman Criddle's notes were particularly valuable in recording close observations on the changes and fluctuations of fauna and flora in the same region for over fifty years, from the time when southwestern Manitoba was largely unsettled prairie, to the present era of intensive cultivation, and still more so because he was an all-round naturalist interested in all nature and cbserved the correlation between the different forms of life." (R. M. Anderson, June, I933).

Mr. Criddle was a member of several scientific and other organizations, in some of which he took a very active interest. Among these may be listedthe Entomological Society of Ontario, the Ottawa Field Naturalists' Club (past 
president), the National Association of Audubon Societies (sustaining member), the American Ornithologists' Union (counsellor and past president), the Manitoba Natural History Society (honourary president), the American Association of Economic Entomologists, the Entomological Society of America, International Great Plains Crop Pest Committee (permanent chaiman), the Professional Instiutic of Civil Servants of Canada, The University Club of Ottawa, and the Ottawa Vegetable Growers' Association (honourary).

On March I Mr. Criddle was honoured by the Manitoba Agricultural College in being awarded the honourary diploma in agriculture as a recognition of the service which he had rendered to the province. This well merited public recornition was the occasion for the greatest satisfaction to his host of personal and professional friends.

The place which he took in the opinion of his scientific colleagues was beautifully stated in the following words by one of them when referring to him in a semi-personal communication to the junior writer following Mr. Criddle's death.

"We all had a great admiration for Norman Criddle and those who knew him well enough, a real affection. He was a fine gentleman in the best sense cf the word and one of the kindest and most truly modest men I have ever known. There is no doubt in my mind that Criddle was the best informed field naturalist in the whole of Canada. In fact there are few of his type anywhere. His death will leave a gap in the ranks of Canadian naturalists which will probably never be filled by any single man."

At the Entomological Sessions of the World's Grain Exxhibition and Conference, July 25, I933, Regina, Saskatchewan, the first formal meeting of a group of Canadian Entomologists following the death of Mr. Criddle, a resolution moved by Dr. I. R. Parker and seconded by Prof. A. G. Ruggles was unaminously passed to the effect-_-

"That the delegates assembled at the Entomological Sessions of the World's Grain Exhibition and Conference at their first meeting, July 25, wish hereby formally to express to his immediate relatives the feeling of intense personal and professional loss experienced by all those in attendance at the meetings, in the leath of Mr. Norman Criddle.

"Mr. Criddle had for so many years taken so prominent and authoritative a part in all prairie entonological activities that with his passing there has come a unanimous realization of having lost an irreplaceable colleague, friend and leader in the science."

ARTHUR GIBSON,

H. G. CRAWFORD.

LIST OF PUBLICATIONS OF THE LATE NORMAN CRIDDLE (MIany contributions to agricultural papers or newsipapers are not inchuded.) ENTOMOLOGY

1907. Tabits of Some Manitoba Tiger Beetles. (Cicindelidae). Can. Ent., 39:105-114.

1910. The Migration of Some Native Locusts. Ann. Rept. Ent. Soc. Ont., 41:60-61. Habits of Some Manitoba Tiger Beetles. Can. Ent., 42:9-15.

1911. Tnjurious Insects of 1910 . Jour. Eoon. Ent., $4: 236-241$.

1912. Beetles in Relation to Agriculture. Nor'-West Farmer, $31: 1593-1595$

Injurious Insects of 1911 at Treesbank, Man. Jour. Econ. Ent., $5: 248-252$.

Injurious Insects of Southern Manitaba. Ann. Rept. Ent. Soc. Ont., 43:97-100. 
Insect migration at Aweme, Man1. Ann. Rept. Ent. Soc. Ont., 42:74-76.

1915. Popular and Economic Entomclogy: 1, Some Inhabitants of a Sand Plain in June. Can. Enit., $47: 24-30$.

Two Useful Inhabitants of Gardens. Man. Hort., May.

The Hessian-Fly and Western Wheat-Stem Sawfly in Manitoba, Saskatchewan and Alberta. Bul. No. 11, Ent. Br., Dept. Agric. Can.

A Garden Cleanup. Man. Hort., 2, No. 9.

1916. The Western Wheat-Stem Sawfly. Sask. Farmer, Oct., $7: 15$.

Some stem maggots attacking growing grain. Agtric. Gaz., 3:504-507.

1917. Further Observations Upon the Habits of the Western Wheal-Stem Sawify in Manitoba and Saskatchewan. Agric. Gaz., 4:176-177.

Poptlar and Practical Entomology: Precipitation in Relation to Insect Prevalience and Distribution. Can. Ent., 49:77-80.

Bands for the Protection of Plants Against Cutworms. Man. Hort., 4: Apri1.

Some habits of Two Burrowing Spiders in Manitoba. Ot. Nat., 31:104-107.

1918. Poptiar and Practical Entomology-Light Traps as a Means of Conitrolting Insect Pests. Can. Ent., 50 :73-76.

The Habits and Control of White Grubs in Manitoba. Agric. Gaz., 5:449-454.

Popular and Practical Entomology-the Egg-Laying Habits of Some of the Acrididae. Can. Ent., $50: 145-151$.

The Large Aspen Tortrix, Cacoecia conflictana Walk. Agric. Gaz., 5:1049-1051.

1919. Fragments in the Life-Habits of Manitoba Insects, Cans. Ent., 51-97-104.

Locusts in Manitoba with Special Reference to the Outbreak of 1919. Anil. Rept. Fint. Soc. Ont., 50:49-53.

1920. Locust Control in the Prairie Provinces. Cir. No. 13, Ent. Br., Dept. Agric. Can. Fragments in the Life-Habits of Manitoba Insects, II. Can. Ent., $52: 121-125$.

Some phases of the Present Locust Outbreak in Manitoba. Ann. Rept. Ent. Soc. Ont., $51: 19-23$.

The Common Insects and Their Control. In "Crop Production in Western Canada," by John Bracken, Chap. 14, pp. 359-383. The Grain Growers' Guide, Winnipeg.

1921. The Control of Grasshoppers. Crop Prot. Lflt., No. 14, Ent. Br., Dept. Agric. Can. Some Phase of the Present Locust Outbreak in Manitoba. Ann. Rept. Ent. Soc. Ont., $51: 19-23$.

The Entomological: Record', 1920. Ann. Rept. Ent. Soc. Ont., $51: 72-90$.

1922. The Western Wheat-Sten Sawfly and Its Control. Pam. No. 10, Ent. Br., Dept. Agric. Can.

Manitoba Grasshoppers. Can. Fld, Nat., 36:41-44, 66-68.

Beetles Injurious to Sunflowers in Manitoba. Can. Ent., $54: 97-99$.

The Western Wheat-Stem Sawfiy in Canada. Ann. Rept. Ent. Soc. Ont., 52:18-22. The Entomological Record, 1921. Ann. Rept. Ent. Soc. Ont., 52:57-70.

1923. The Hessianl-Fly in the Prairie Provinces. Pam. No. 30, NS., Ent. Br., Dept. Agric. Can.

The Life-Histery of Cephus cinctus Nort. in Manitoba. Can. Enit, $51: 1-4$.

Superheating for Household Pests. Can. F1d. Nat., 37:52-53.

The Entomological Record, 1922. Ann. Rept. Ent. Soc. Ont., 53:76-90.

1924. Notes on the Early Stages of Grasshoppers. Can. Ent., $51: 49-53$.

Two Problems in Natural Control. Ann. Rept. Ent. Soc. Ont, $54: 16-18$.

The Entomological Record, 1923. Anns. Rept. Ent. Sor. Ont., 54:87-102.

Observations on the Habits of Sphex procera in Manitoba. 'Can. Fid. Nat., $38: 121-123$.

1925. Field Crickets in Manitoba. Can. iFnt., $57: 79-84$.

A new Cicindela from the adjacent territory of Wontana and Aiberta. Can. Ent, $57: 127-128$.

Lessons From the Grasshopper Outbreak of 1919-23 in Manitoba. Ann. Rest. Ent. Soc. Ont., 55:13-16.

The Fintomological Record, 1924. Ann. Rept. Ent. Soc. Ont. 55:89-106.

1926. Notes on the Synonymy of Certain Species of Physonota. Can. Ent., 58:207-208.

The Entomological Record, 1925. Ann. Rept. Ent. Soc. Ont., 56:94-107.

Life-Fistory and IIabits of Anabrus longipes Caud. (Orthoptera). Can. Fint, $58: 261-265$.

Studies of the Immature Stages of Manitoban Orthoptera. Trans. Roy. Soc. Cann., 20:505-525.

1927. The Western Wheat-Stem Sawfily. Eatonis Farm News Service. Lepidoptera reared in Manitoba from poison ivy. Can. Ent., 49:99-101.

The Entomological Record, 1926. Ann. Rept. Ent. Soc. Ont., 57:47-62.

1928. The Entomological Records, 1927. Ann. Rept. Ent. Soc. Ont., 58:92-103. The Introduction and Establishment of the Iarch Sawfly Parasite, Mesoleins tenthredinis Morley, in Southern Manitcba. Can. Ent., 40:51-53.

1929. The Entomological Record, 1928. Ann. Rept. Fnt. Soc. Ont., 59:110-124.

Insects of the Season in Manitoba. Ann. Rept. Ent. Soc. Ont., 59:22-26 (with 
A. V. Mitchener).

1930. The Life-History of the Cow Giasshopper, Chrysochraon abdominalis in Manitoba. Ca11. Ent., $62: 24-28$.

1931. Insects of the Season in Manitoba. Ann. Rept. Ent. Soc. Ont., $61: 20-23$ (with A. V. Mitchener).

Grasshopper Conitrol in Canada East of the Rocky Mountains. Bull. No. 31, Ent. Br., Dept. Agric. Can.

1932. The Life-History of Schistocerca lineala Sind. Can. Ent., 64:98-102. Strggestions for the Control of Grasshoppers. Rhineland Agric. Soc. Quarterly, Vol. 2, No. 2.

The Correlation of Sun Spot Periodicity With Grasshopper Fluctuation in Manitoba. Can. Fid: Nat., 46:195-199.

1933. Map-Areas in Manitoba Likely to Be Infested by Grasshoppers in 1933. Ent. Br., Dept. Agric. Cant.

Notes on the Habits of Injurious Grasshoppers in Manitoba. Can. Ent. 65:07-102. Lema trilineata Oliv. in Manitoiba (Coleoptera, Chrysomelidac). Can. Ent. 65:150-151 with R. H. Handiford).

Studies in the Biology of the North American Acrididae. Part 1, The Ego-Sac and Egg. (In manuscript).

The Biology of Grasshoppers of the Canadian Prairies. (In manuscript).

\section{ORNITHOLOGY}

1904. The Wountain Blue Bird! in Manitoba. Ott. Nat., 18:85-86

1906. The Golden Winged Waxbler in Manitoba. Ott. Nat., 20:112.

An addition to Onr Manitoba Warblers. Ott. Nat., 20:189.

1908. Some Bird Habits. Ott. Nat., $22: 153-156$.

'The Economic Value of Some Common Birds. Nor'-West Farmer, $27: 1153-1155$.

1909. How the English Sparrow is Actapiting Itself to New Conditions of Life. Ott. Nat., $23: 23-25$.

1910. Every day ornithology. Ott. Nat., $23: 197-204$.

A Colony of Clifif Swallows and Others. Ott. Nat., 24:143-145.

1911. Our Common. Winter Birds. Nor'-West Farmer, 30:119-i23.

Food Habits of the Snowbird. Nor'-West Farmer, 20:256.

Poptilar and Practical Ornithology: 1, the Snowflake. Ott. Nat., 25:125-128.

1012. Popular and Practical Ornithology: 2, the Marsh Hawk. Ott. Nat., 25:147-151.

Popular and Practical Ornithology: 3, the Upland! Plover. Ott. Nat., 26:61-65.

1014. 'The American Crow. Nor'-West Farmer, 33:468-470.

1915. Sonne Habits of Swainson's Hawk in Mantoba. Ott. Nat., $20: 94-97$.

1917. Horned Larks at Aweme, Man. Ott. Nat., 30:144-148 (with Stuart Criddle). The American Crow in Relation to Agriculture. Agric. Gaz., 4:446-450.

The Red-Tailed Hawk in Manitoba. Ott. Nat., $21: 74-76$.

1918. The House Sparrow and Brown Rat in the Prairie Provinces of Canada. Agric. Gaz., 5:348-349.

1919. Birds in Relation to Sunflower Growing in Manitoba, Can. Fild. Nat., 33:90 92.

1920. The Birds of a Manitoba Garden. The Western Gardener, 5: Feb.

Notes on the Nesting Habits and Food of Prairie Horned Larks in Manitoba. Can. F1d. Nat., $34: 14-16$.

Birds in Relation to Insect Control. Can. F1d. Nat.. 34:151-153.

1921. Birds That Are Little Known in Manitoba. Can. Fid. Nat, 35:133-135.

1922. A Calendar of Bird Migration. Auk, 39:41-49.

1923. The American Magpie in Manitoha. Can. F1d. Nat., $37: 25-26$.

Some Winlter Birds of the Midclle West. The War Cry, Dec.

1927. Habits of the Monintan Blue Bird in Manitolu. Can. Fld. Nat., 41:40-44.

A Tale oif Four Crows. Can. Fild. Nat., $41: 179-183$.

1930. Some Natural Factors Governing the Fluctuation of Grouse in Manitoba. Can. Fld. Nat. $44: 77-80$.

1932. The Number of Fegs Per Nest of the Vesner Sparrow. Bird Banding, 3:114-115. BOTANY

1907. How the Seeds of Planits Are Sipread in Nature. IOtt. Nat., 22:27-31.

1909. The So-Called White Wild Oats and What They Are. Ott. Nat.. $23: 127-128$.

Some Facts About Wild Oats. Non-West Farmer, 28:1117-1118.

1910. The Sitatus of False Wild Oats. Ann. Rept. Seed Growers Assoc. 6:104-105.

1912. Wild Oats and False Wild Oats. Buil. No. S-7, Seed Br., Dent. Aric. Can.

1915. A Note on the Colout of Tumbling Mustard Secd. Ott. Nat., 28:138-139.

1027. A Calenciar of Flowers, Can. Fld. Nat., 41:48-55. MAMMALOGY AND WILD LIEE

1906. The Fily Agaric Amanita muscarda and How It Affects Catile. Ott. Nat., $19: 203-204$

1911. Natural History Notes from Calgary. Alta. Ott. Nat., 25:73-76.

1913. The Broad-Striped Skunk (Mephitis hudsomicus Rich.) Ott. Nat., 27:46-49 (with Stuart Criddle.) 
1914. Grophers of the Praitie Provinces and Their Control. Encyclopedea.

The Value of Some Mammals and Birds as Destroyers of Noxious Insects. Ott. Nat., $28: 119-124$.

19:15. Some Canadian Rodents Injurious to Agriculture. Agric. Gaz., 2:110-114.

1917. Varying Hares of the Prairie Provinces. Agric. Gaz., 4:260-263.

1918. The House Sparrow and Brown Rat in the Prairie Provinces of Canada. Agric. Gaz., $5: 348-349$.

1922. The Relation of Wild-Life to Agriculture. Can. Fld. Nat., 36:47-49.

1923. The Coyote in Manitoba. Can. Fld. Nat., $37: 41-45$ (with Evelyn and Stuart Criddle).

1925. Weasels of Southern Manitoba. Can. Fld. Nat., 39:142-148 (with Stuart Criddle). The Habits and Economic Importance of Wolves in Canada. Bu11. No. 13, New Series, Dept. Agric. Can.

\section{MTSCELTANEOUS}

1920. Obituary-C. Gordon Hewitt. Can. Fld. Nat., 34:174-176.

1927. Book Review-Report of the Game Commissioner for Saskatchewan. Can. F1d. Nat., $45: 20-21$.

1929, Obituary-Hugh McKellar. Can. Ent., $61: 288$.

Book Review-A Mantual of External: Parasites by H. E. Ewing. Can. Fld. Nat., $43: 190$

1930. Book Review-Insects, Ticks and Vemomous Animals of Veterinary and Medical Importanoe. Can. Flid. Nat., 44:169-170.

1931. Obituary-James H. Emerton. Can. Fld. Nat., $45: 00$.

1932. Book Review-Common Pests, etc. Can. Fid. Nat., 46:193-194.

\section{NOTES ON NORTH AMERICAN LEPIDOPTERA WITH DESCRIP'TIONS OF NEW SPFCIES* \\ BY J. MCDUNNOUGH. Ottawa, Ontario. NOCTUIDAE.}

\section{Agrotis mollis Wlk.}

Agrotis mollis Walker, 1856, Cat. Lep. Het. Brit. Mus, X, 333

Alyrotis jernaldi Morrison, 1875, Proc. Acad. Nat. Sci. Phil. 429; Grote, 1882, I11. Essay, 53, Pl. I, fig. 11.

Euxoa mollis Hampson, 1903, Cat. Lep. Phal. Brit. Mus. IV, 272, P1. LXV, fig. 4; McDunnough, 1929, Bu11. 55, Can. Nat. Mus. 74.

This species, which in all the later lists has been placed in the genus Euxoa, will have to be transferred to Agrotis on the strength of the male genitalia which are typical of this latter genus; the front, furthermore, is only slightly bulging and roughened and does not show the tubercle with raised edges claracteristic of most of the Euroa species. The rough, hairy squammation may be matched by several species included in Agrotis in my revision (1929, Bull. 55, Can. Nat. Mus. 34) but the fasciculate male antennae are only duplicated by vetusta W11. and the forewings are shorter and broader than ustial. There appear to be no very close relatives.

\section{Agrotis dolli Grt.}

When preparing my generic revision of Agrotids I was unable to examme a specimen of this species; it was therefore not mentioned in my text but left, in my list of species (p. 75), in its usual place next to daedalus Sm. Since then I have received two males from Presidio, Tex., one of which has been kindly identified for me by Mr. F. H. Benjanin, of the United States National Museum, as this species. The proper generic position for the species is rather doulbtful; in my key it would run to Protogygia, due to the lack of the fourth row of tarsal spines found in Agrotis; this same feature would preclude placing in Onychagrotis where is would otherwise fall quite well on account of the rather short and

* Contribution from the Division of Systematic Entomology, Entomological Branch, Dept. of Agric., Ottawa. 